\title{
Informal Labours in Kolkata City: Migration from Undivided Bihar and Uttar Pradesh
}

\section{Sumita Roy ${ }^{\dagger *}$ and Gopa Samanta ${ }^{*}$}

\section{Abstract}

Migration takes place due to various social, cultural, economic or political reasons. Previous Census reports of India show that employment-induced out-migration is a common feature of several states like Bihar, Jharkhand, Uttar Pradesh, and other states. In the case of Kolkata, informal labours have enormous employment opportunities in big business centres and small manufacturing units of the city. With the help of D-series Census Data of the years 1961, 1971, 1981, 1991, 2001 and 2011, this study focuses on the migration pattern and the reasons for migration to Kolkata. Secondary data fails to give an idea about the migration pattern of non-Bengali informal labours in the city. Through intensive field survey, the present study tries to identify the dominance of non-Bengali single (without family) male labour migration and to explore the migration streams to the informal sectors of Kolkata. With the help of both secondary data on migration over different decades and by using the primary data, the article argues that non-Bengali migrants represent the informal labour community in Kolkata especially from undivided Bihar and Uttar Pradesh, and the pattern of migration is mainly occupation-induced single male labour migration.

Keywords: Non-Bengali Informal labour; Single Male Migration; Factors for Migration; Kolkata; West Bengal

\footnotetext{
${ }^{+}$PhD Scholar, Department of Geography, The University of Burdwan

${ }^{*}$ Corresponding Author, Email: sumitaroy.in@gmail.com

¥ Professor, Department of Geography, The University of Burdwan

(C) 2020 Roy \& Samanta. This is an Open Access article distributed under the terms of the Creative Commons Attribution License (http://creativecommons.org/licenses/by/2.0), which permits unrestricted use, distribution, and reproduction in any medium, provided the original work is properly cited.
} 


\section{Introduction}

Migration is a process that moves cultures, resources and ideas from one place to another. For a vast country like India, the complexity of movement of population in different parts of the country helps in understanding the dynamics of the society. 'A culture of migration is now part of the Indian social fabric and has become so deeply rooted in the cultural landscape of some states' (Bhatt, 2009, p. 90). Rural to urban population displacement is one of the main reasons of urbanisation during 2001 to 2011, and the southern states including West Bengal show a higher level of urbanisation than the national average (Bhagat, 2011).

Kolkata has experienced in-migration since the time it started to experience growth, as it was the capital of the British in India till 1911. People migrated to the city not only from the nearby states like Bihar, Orissa and Assam but also from distant states like Punjab, Tamil Nadu and Kerala. A large number of Nepalese, Chinese and Bangladeshis (after the partition of 1947) have also migrated to the city (UNICEF, 2014). Kolkata was the only metropolitan city in eastern India with enormous employment opportunities in the industrial sector. Therefore, the city attracted a massive migrant labour force from the whole of eastern India (De Haan, 1997). In another study, De Haan (2000) stated that the labours involved in different informal sectors in Kolkata are mainly migrants. Field survey also shows that there is a wide-ranging informal economy in the city which is mainly occupied by inter-state migrant labour from undivided Bihar and Uttar Pradesh.

This study begins with a description of the methodology deployed here. It argues the reasons for selecting this specific region and database. The next section gives a brief historical background of informal labour migration to the region, followed by a description of the changes in the flow of this migration over time. We identify the gendered pattern of migration and locate the dominant source regions for the migrants. The next section explores at length the reasons why Kolkata has emerged as a popular site for migration of informal labours from these regions. Since the majority of these migrant workers have strong agrarian roots, the next section explores the relationship between agriculture and migration. The conclusion summarises the main findings and arguments of the study and highlights the importance of personal networks in perpetuating the migration patterns from one source area over time.

\section{Database and Methodology}

A considerable amount of work has already been done on industrial labours of West Bengal by several scholars (Bhattacharya, \& Chatterjee, 1973; De Haan, 1999; Sen, 1999). However, there is a literature gap on informal migrant labours in the market areas and small manufacturing units of Kolkata. That is why in this study, informal labours of industries have intentionally not been considered. Migrant informal labours have been targeted for this study after analysing the economic activities of inter-state and inter-district migrants of Kolkata city from the Census Report of 2001. In the report of Census of India, economic activities of migrant workers are divided into eighteen categories, under which two categories which are concentrated by informal labours are dominated by migrants from other states (Table 1). These sectors are 'other than household industry' or manufacturing units, and 'wholesale and retail trade' or business areas. In Kolkata, both the sectors are dominated by migrants from other states.

To understand the migration pattern of the nonBengali informal labours, D-series migration data of the Census of India from 1961, 1971, 1981, 1991, 2001, and 2011 have been analysed. Reasons of migration have been examined from the year 1981 to 2011 as it is not available for the previous years. Considering, the Slum Survey Report (2009), two market places that is Posta Bazar and Burrabazar and two manufacturing units that is Kailash Bose Street and Tangra have been chosen for the present study, based on high concentration of the non-Bengali population and the number of labour. Considering 30 labours from each unit, a total of 
120 labours have been interviewed. The These inter-state migrant labours are mostly interviews were taken in Hindi, mostly on working as permanent informal labour, floating weekends and later were transcribed in English. labour, van drivers and porters in the city.

\begin{tabular}{|c|c|c|c|c|}
\hline \multirow[t]{2}{*}{ Economic Activity of Migrants in Kolkata } & \multicolumn{2}{|c|}{$\begin{array}{c}\text { Migrants from the } \\
\text { Other States of } \\
\text { India }\end{array}$} & \multicolumn{2}{|c|}{$\begin{array}{c}\text { Migrants from } \\
\text { Other Districts of } \\
\text { WB }\end{array}$} \\
\hline & No. & $\%$ & No. & $\%$ \\
\hline Cultivator & 595 & 0.22 & 523 & 0.29 \\
\hline Agricultural Labour & 585 & 0.22 & 506 & 0.28 \\
\hline $\begin{array}{l}\text { Plantation, Livestock, Forestry, Fishing, Hunting and } \\
\text { Allied Activities }\end{array}$ & 1,288 & 0.45 & 526 & 0.29 \\
\hline Mining and Quarrying & 436 & 0.16 & 382 & 0.21 \\
\hline Household Industry & 6,602 & 2.40 & 4,322 & 2.38 \\
\hline Other than Household Industry & 45,900 & 16.70 & 25,332 & 13.97 \\
\hline Electricity, Gas and Water Supply & 1,894 & 0.68 & 1,086 & 0.60 \\
\hline Construction & 12,250 & 4.46 & 11,740 & 6.47 \\
\hline Wholesale and Retail Trade & 65,994 & 24.00 & 29,958 & 16.51 \\
\hline Hotels and Restaurants & 8,188 & 2.98 & 3,850 & 2.12 \\
\hline Transport, Storage and Communications & 39,226 & 14.27 & 15,794 & 8.71 \\
\hline $\begin{array}{l}\text { Financial Intermediation, Real Estate, Renting and } \\
\text { Business Activities }\end{array}$ & 27,640 & 10.05 & 21,856 & 12.05 \\
\hline $\begin{array}{l}\text { Public administration and defence, Compulsory and } \\
\text { Social Security }\end{array}$ & 64,282 & 23.38 & 65,526 & 36.12 \\
\hline Education & & & & \\
\hline Health and Social Work & & & & \\
\hline $\begin{array}{l}\text { Other Community, Social and Personal Service } \\
\text { Activities }\end{array}$ & & & & \\
\hline A private household with employed persons & & & & \\
\hline Extra-Territorial Organisations and bodies & & & & \\
\hline Total & 274,880 & 100 & 181,401 & 100 \\
\hline
\end{tabular}

\section{A Brief Account of Migrant Informal Labours of} Kolkata City

Most of the informal labours of the city are migrants from Bihar, Jharkhand and Uttar Pradesh. More than three-fourths of the interviewed labours are Hindu by religion and around half of them belong to the scheduled caste (SC) category ${ }^{1}$. Our observations indicate that the highest proportion of these labours lies in the 31-40 years age group and the second- highest is below 30 years. Most of these labours have migrated to this city in last ten years and the second-highest portion has migrated between the last 11 to 20 years, which indicates new entries in the informal labour sector of the city. Around 70 to 93 per cent of the interviewed labours are married. Still, they have migrated to the city alone without their family, as most of the labours possess agricultural lands, cattle and other properties in their native places that need

\footnotetext{
${ }^{1}$ Field survey depicts the fact that in most of the cases, the people belong to lower caste are tending to more migratory due to scarcity of agricultural land.
} 
to be looked after. Though the monthly income varies from INR 12,000 to 15,000 , being the sole earner of the family, it is challenging for most of the labours to support their family with ease. It is more difficult for them as there is no existing policy for migrant labours in West Bengal. Though the state government has implemented the Samajik Suraksha Yojona for the welfare of informal labours, the main criterion of enrolling under the scheme is that the labour should be a permanent resident of the state. Moreover, more than half of the interviewed labours have five to six people in their family who are all economically dependent on the labour. Therefore, remittance is the only hope for the family members of most of the labours. Most of the labours have not completed school education, so in many cases, due to lack of education, the labours are unable to send remittances via banks. Therefore, they have to depend upon Dakiyas, ${ }^{2}$ friends and relatives who work in the city, and e-money sending shops (over the past few years, some shops which were previously working for recharging money for mobiles are now acting as money senders via different mobile apps such as Google Pay, BHIM, etc.). Nowadays, many labours are moving from Dakiyas to e-money sending shops due to lower transferring charge.

\section{Inter-State Single Male Migration: Flow and Changes Over Time}

Many social scientists have emphasised upon patterns of migration from different perspectives (Dasgupta, 1982; De Haan, 1997; Rao, 1973; Rele, 1969; Singh, 1984; Skeldon, 1986; Zachariah, 1964). Majority of these scholars have discussed the migration pattern of India with reference to the types of region, that is, rural and urban. In general, rural-to-urban migration is more dominant in India. However, Dasgupta (1982) stated that rural-to-urban migration in India declined in the year 1981 in comparison to the previous two decades. Here, in this study, we have focused on the gendered pattern of migration, dominant source of migrants, and the space-specific reasons for migration from different states to understand the dominance of inter-state single male migration in Kolkata.

\section{Gendered Pattern of Migration}

Skeldon (1986) has analysed the relation between gender and the destination area. Considering the total migration of India, rural-torural and rural-to-urban movements are dominated by women. After analysing the Census data of 1971 for the three states of Bihar, West Bengal and Kerala, Singh (1985) opined that single males are 'prone to be more migratory' than married males. Zachariah (1964), Rele (1969), Rao (1973) and Singh (1984) have identified marriage as a major reason for female migration, and employment opportunities as a primary reason for male migration. The number of male migrants to Kolkata was around 0.60 million in 2011, which equated to around 54.57 per cent of the total male migrants to West Bengal in that year. Therefore, the male in-migration to Kolkata was the highest in comparison to that of the other districts of West Bengal. This observation matches some of the laws as propounded by Ravenstein almost more than 100 years ago which states that in general, females are larger migrants than males and people migrate to a long distance if the destination is 'one of the great centres of commerce or industry' (Ravenstein, 1885, p. 199).

Further, Tobler (1995) has said that the migration system can be characterized as being "sluggish" in both space and time' (p. 336). However, the gender-wise trend line has taken only 50 years to show a drastic change (Figure 1). Between 1961 and 2011, the percentage of female in-migration to Kolkata has increased from around 21 to 43 per cent. Even so, the number of male migrants still occupies a higher position in comparison to the female migrants in Kolkata city.

The total male migration to the city has decreased suddenly in the year 1991. According to Rana (2018), in between 1980 to 1990, people

\footnotetext{
${ }^{2}$ Dakiyas are money carriers from their native places who charge 5 to 10 per cent of the amount to be sent.
} 
from rural Bihar and Uttar Pradesh changed their destination from the jute mills of Kolkata to the agricultural fields of Punjab as most of the jute mills had converted to real estate business. The number of male migrants again decreased in 2011, which indicates either shrinking work opportunities in the city or increasing work opportunities in the source regions.

Though the Census data of 2011 indicates that among the total inter-state migrants to Kolkata, around 43 per cent are female, field observation on the informal labours in Kolkata depicts the dominance of single male migration. Mostly two reasons are responsible for this type of migration. Firstly, single male migration was dominant in Kolkata due to better employment opportunities in the city (Rele, 1969 and De Haan, 2002). Secondly, living cost in the urban areas is quite high with respect to rural areas (Das and Das, 2014) which resist them to migrate with their family. Among the 120 interviewed informal labours, only one labour of Tangra, has migrated with his family. He stated that previously he migrated to this city, leaving his family in his village. After around six years of having migrated, he brought his family to a small room which he rented in a slum in Kolkata. He has said that his two brothers are there in the village to look after the agricultural land only because of which he could shift his family to Kolkata.

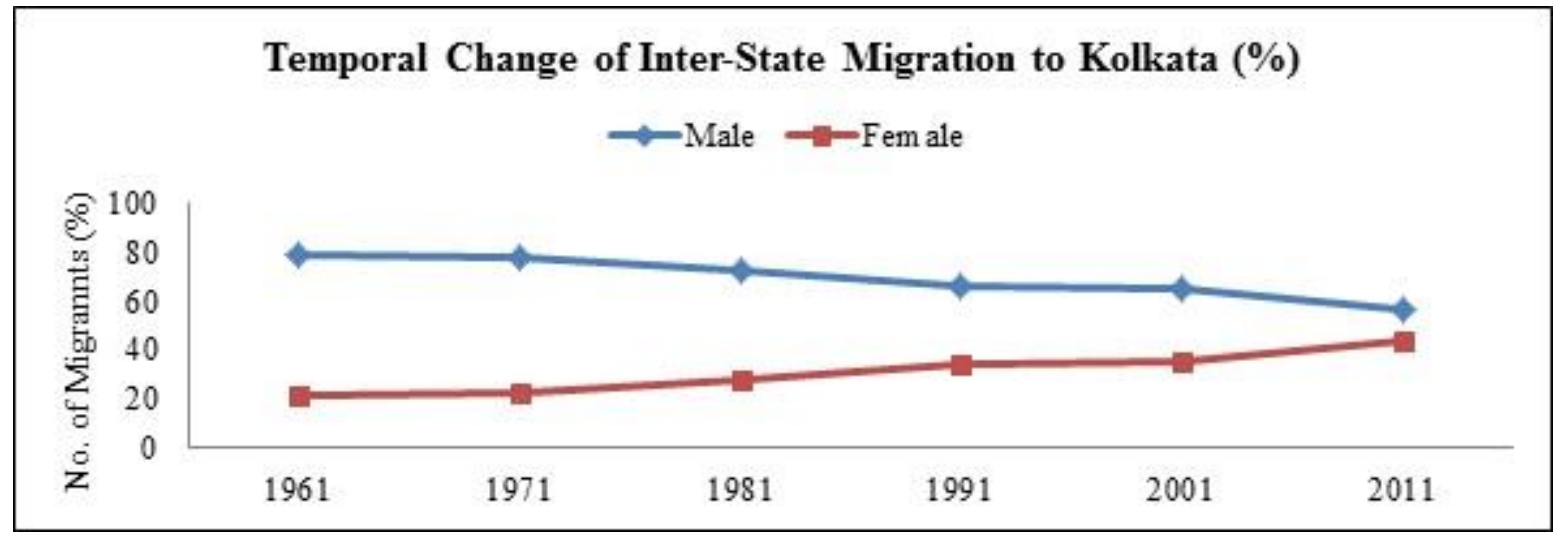

Figure 1

Source: Census of India, D-Series, West Bengal, 1961, 1971, 1981, 1991, 2001, 2011

\section{Dominant Regions in Labour Migration}

With the development of cities, in-migration to those places increases mainly in order to avail more employment opportunities. According to a report by Narain and Bhattacharya, (2012, p. 49), 'during the colonial period, the rise of the port cities of Bombay, Calcutta and Madras led to a massive migration from Bihar and Uttar Pradesh to these cities in search of work'. Similarly, a report of the Overseas Development Institute by Deshingkar et al. (2006) revealed that migration from Bihar to Kolkata, Assam and Punjab is not a recent phenomenon.

According to the Census reports, the number of total migrants to Kolkata was around 1.54 million in 1961, which increased to 5.76 million in 2011 (Table 2). Inter-state migration was always higher than inter-district migration to
Kolkata, except for the recent census period. Bihar has occupied the highest position with respect to the rate of migration from other states of India to Kolkata. The percentage of migrants from undivided Bihar among the total inter-state migrants to Kolkata is more than 50 per cent since 1961. According to the Census Report of 2011, among the total migrants to West Bengal from Bihar, 51.83 per cent are staying in Kolkata. This indicates that the trend of migration from Bihar and Uttar Pradesh is more significant in Kolkata in comparison to the other districts of West Bengal.

The data source, however, fails to identify the source region of the labours. Empirical research shows that most of the surveyed labours of Burrabazar, Posta and Kailash Bose Street have migrated from Bihar, in numbers which range from 60 to around 87 per cent (Table 3). In case 
of Posta Bazar, around 83 per cent labours have migrated here from Bihar, of which around 23 per cent are from Bhagalpur. It is found that around 87 per cent have come to this city from different districts of Bihar among which around a quarter of the total interviewed labours have migrated from Banka district. A high concentration of more than one-third of the interviewed labours of Kailash Bose Street also belongs to a particular district, Muzaffarpur in Bihar. In Kailash Bose Street, the number of migrants from Uttar Pradesh is quite high, at 40 per cent of the surveyed labours. Another migration stream is seen from different villages of Ambedkar Nagar of Uttar Pradesh to Kailash Bose Street. In Tangra, all the surveyed labours are from Bihar, and surprisingly, 80 per cent of them belong to Banka district.

\begin{tabular}{|c|c|c|c|c|c|c|c|c|c|c|}
\hline \multirow[t]{2}{*}{$\begin{array}{c}\text { Kolkata } \\
\text { UA }\end{array}$} & \multirow{2}{*}{$\begin{array}{l}\text { Total } \\
\text { No. }\end{array}$} & \multirow{2}{*}{$\begin{array}{l}\text { Other } \\
\text { Districts of } \\
\quad \text { WB } \\
\text { No. }\end{array}$} & \multicolumn{2}{|c|}{$\begin{array}{l}\text { Other States of } \\
\text { India }\end{array}$} & \multicolumn{2}{|c|}{ Bihar } & \multicolumn{2}{|c|}{$\begin{array}{c}\text { Uttar } \\
\text { Pradesh }\end{array}$} & \multicolumn{2}{|c|}{$\begin{array}{c}\text { Jharkhan } \\
\text { d }\end{array}$} \\
\hline & & & No. & $\%$ & No. & $\%$ & No. & $\%$ & No & $\%$ \\
\hline 1961 & 1541743 & 310064 & 679940 & 100 & 345349 & 51 & 130564 & 19 & N.A. & N.A. \\
\hline 1971 & 2276985 & 518025 & 1012135 & 100 & 546240 & 54 & 230570 & 19 & N.A. & N.A. \\
\hline 1981 & 2876316 & 594935 & 1112119 & 100 & 589555 & 53 & 255754 & 23 & N.A. & N.A. \\
\hline 1991 & 2617626 & 639871 & 882136 & 100 & 500110 & 57 & 179420 & 20 & N.A. & $\begin{array}{l}\text { N. } \\
\text { A. }\end{array}$ \\
\hline 2001 & 3735752 & 1138925 & 1179552 & 100 & 625116 & 53 & 200715 & 17 & $\begin{array}{l}8010 \\
1\end{array}$ & 6.79 \\
\hline 2011 & 5760770 & 2167506 & 1050967 & 100 & 572071 & 54 & 156189 & 15 & $\begin{array}{l}7709 \\
9\end{array}$ & 7.33 \\
\hline
\end{tabular}

Source: Census of India, D-Series, West Bengal, 1961, 1971, 1981, 1991, 2001, 2011

Empirical research shows that people from village areas migrate to those areas where their friends, neighbours or relatives have previously migrated and settled down. In these cases, they can get an idea of that city or that place, which makes the decision of migration easier for them. Therefore, when a labourer from a particular source region enters another area for employment opportunities, then new entries from that source region keep on continuing. From the above study, five steady migration streams to Kolkata have been identified, among which four are from Bihar, and one is from Uttar Pradesh. These streams are: Bhagalpur district of Bihar to Posta Bazar, Banka district of Bihar to Burrabazar, Muzaffarpur district of Bihar to Kailash Bose Street, Ambedkar Nagar of Uttar Pradesh to Kailash Bose Street, and Banka district of Bihar to Tangra. Further analysis of the stream from Banka district to Tangra indicates that around a quarter of the interviewed labours are from the village Chutiya. No other village from any district has identified with this level of out-migration to Kolkata city.

\section{Why have Inter-State Migrants migrated to Kolkata?}

According to Roy (1991), in most cases, industries are located in urban areas, and megacities are no exception. Due to this, the influx of rural people to urban areas is a common phenomenon. Roy et al. (2015) argues that, employment-induced migration is a predominant feature in the villages of Bihar. Census reports highlight that the primary reason for migration from Bihar and Uttar Pradesh to Kolkata Urban Agglomeration is 'work or employment' (Figure 2 and Figure 3). The actual number of male migrants from Bihar for the reason 'work or employment' was quite high in 2011, at 0.38 million. Between 1981 and 2011, the shared percentage of employment-induced male migration in comparison to the total male migrants has decreased from 64.59 to 45.38 per cent in Kolkata. 


\begin{tabular}{|c|c|c|c|c|c|c|c|}
\hline \multicolumn{8}{|c|}{ Posta Bazar } \\
\hline State & District & Village & $\begin{array}{l}\text { Migrants } \\
\text { (\%) }\end{array}$ & State & District & Village & $\begin{array}{l}\text { Migrants } \\
\text { (\%) }\end{array}$ \\
\hline \multirow[t]{5}{*}{ Bihar } & Bhagalpur & $\begin{array}{l}\text { Ramnagar, } \\
\text { Nayatola }\end{array}$ & 23 & \multirow[t]{2}{*}{ Bihar } & Samastipur & Muraha & 7 \\
\hline & Munger & Rajgur, Baukhra & 7 & & Darbhanga & $\begin{array}{l}\text { Pakahi, } \\
\text { Kabirchak }\end{array}$ & 13 \\
\hline & Patna & $\begin{array}{l}\text { Pundarakh, } \\
\text { Darwe Bhadaur, } \\
\text { Bihari bigha }\end{array}$ & 17 & \multirow[t]{3}{*}{ Jharkhand } & Chatra & $\begin{array}{l}\text { Basaria, Kacha, } \\
\text { Nawada }\end{array}$ & 10 \\
\hline & Begusarai & Bagwara & 10 & & Lohardaga & Kutmu & 3 \\
\hline & Lakhisarai & Girdharpur & 7 & & Giridih & Tikodih & 3 \\
\hline \multicolumn{8}{|c|}{ Burrabazar } \\
\hline State & District & Village & $\begin{array}{l}\text { Migrants } \\
\text { (\%) }\end{array}$ & State & District & Village & $\begin{array}{l}\text { Migrants } \\
\text { (\%) }\end{array}$ \\
\hline \multirow[t]{6}{*}{ Bihar } & Banka & $\begin{array}{l}\text { Basdeopur, } \\
\text { Mujahidpur, } \\
\text { Butwaria, } \\
\text { Sakarhar }\end{array}$ & 23 & \multirow[t]{3}{*}{ Bihar } & Patna & Manikpur & 3 \\
\hline & Vaishali & $\begin{array}{l}\text { Salempur, } \\
\text { Rampur dayal }\end{array}$ & 10 & & Bhagalpur & Kajraili & 7 \\
\hline & Madhubani & $\begin{array}{l}\text { Sadulahpur, } \\
\text { Godhanpur, } \\
\text { Madhwapur, }\end{array}$ & 7 & & Khagaria & Rampur & 3 \\
\hline & Muzaffarpur & Simiri, Repura & 13 & Jharkhand & Giridih & Doranda & 3 \\
\hline & Darbhanga & Pakahi & 13 & \multirow{2}{*}{$\begin{array}{l}\text { Uttar } \\
\text { Pradesh }\end{array}$} & Allahabad & Dahi & 3 \\
\hline & Samastipur & Bharwara & 7 & & Varanasi & Kashipur & 7 \\
\hline \multicolumn{8}{|c|}{ Kailash Bose Street } \\
\hline State & District & Village & $\begin{array}{l}\text { Migrants } \\
\text { (\%) }\end{array}$ & State & District & Village & $\begin{array}{l}\text { Migrants } \\
\text { (\%) }\end{array}$ \\
\hline \multirow[t]{5}{*}{ Bihar } & Darbhanga & $\begin{array}{l}\text { Bihari Makund, } \\
\text { Kewatsa }\end{array}$ & 13 & \multirow[t]{5}{*}{$\begin{array}{l}\text { Uttar } \\
\text { Pradesh }\end{array}$} & Gariakothi & $\begin{array}{l}\text { Sultanpur } \\
\text { Khurd, }\end{array}$ & 3 \\
\hline & Muzaffarpur & $\begin{array}{l}\text { Katai, Ratwara, } \\
\text { Ratwara } \\
\text { Bindwara, Jonki, } \\
\text { Gidha, Gokhula }\end{array}$ & 37 & & $\begin{array}{l}\text { Ambedkar } \\
\text { Nagar }\end{array}$ & $\begin{array}{l}\text { Bhiyav, Purwa, } \\
\text { Bhagwanpur, } \\
\text { Ganepur } \\
\text { Patoha, Gopari } \\
\text { Chandpur, } \\
\text { Asharafpur } \\
\text { Bhua, Umarpur, } \\
\text { Gohila, Nimtini }\end{array}$ & 23 \\
\hline & Sitamarhi & Thahar & 3 & & Sultanpur & Khalispur & 3 \\
\hline & Madhubani & Pithwa Tol & 3 & & Faizabad & Jalalpur & 3 \\
\hline & Patna & Bihari Bigha & 3 & & Azamgarh & $\begin{array}{l}\text { Bhaupur, pipari, } \\
\text { Budhanpur, } \\
\text { Mirpur }\end{array}$ & 7 \\
\hline \multicolumn{8}{|c|}{ Tangra } \\
\hline State & District & Village & $\begin{array}{l}\text { Migrants } \\
\text { (\%) }\end{array}$ & State & District & Village & $\begin{array}{l}\text { Migrants } \\
\text { (\%) }\end{array}$ \\
\hline \multirow[t]{3}{*}{ Bihar } & Banka & $\begin{array}{l}\text { Mujahidpur, } \\
\text { Chutiya, } \\
\text { Khushalpur, } \\
\text { Ballikita, Nanua } \\
\text { Chak, Keshopur, } \\
\text { Khajur Koraman, } \\
\text { Jat kuthiya, Tej } \\
\text { pur, Basdeopur, } \\
\text { Pawai, Badrar, } \\
\text { Balarpur, } \\
\text { Kakwara }\end{array}$ & 80 & \multirow[t]{3}{*}{ Bihar } & Bhagalpur & $\begin{array}{l}\text { Sanhoula, } \\
\text { Baluachak }\end{array}$ & 7 \\
\hline & Darbhanga & Pakahi & 7 & & \multirow[t]{2}{*}{ Begusarai } & Bagwara & 3 \\
\hline & Samastipur & $\begin{array}{l}\text { Balbhadarpur, } \\
\text { Daudpur }\end{array}$ & 3 & & & & \\
\hline
\end{tabular}


In this period, the number of employmentinduced male migrants from Uttar Pradesh has also decreased significantly. Following Rana (2018) and Sharma (2015), it can be assumed that economic growth of Bihar and Uttar Pradesh and stagnation of jute mills of West Bengal are the primary reasons for the decreasing share of employment-induced migration from Bihar and Uttar Pradesh to Kolkata. Still, on the whole, the macro data highlights the dominancy of 'work or employment' induced migration. Banerjee

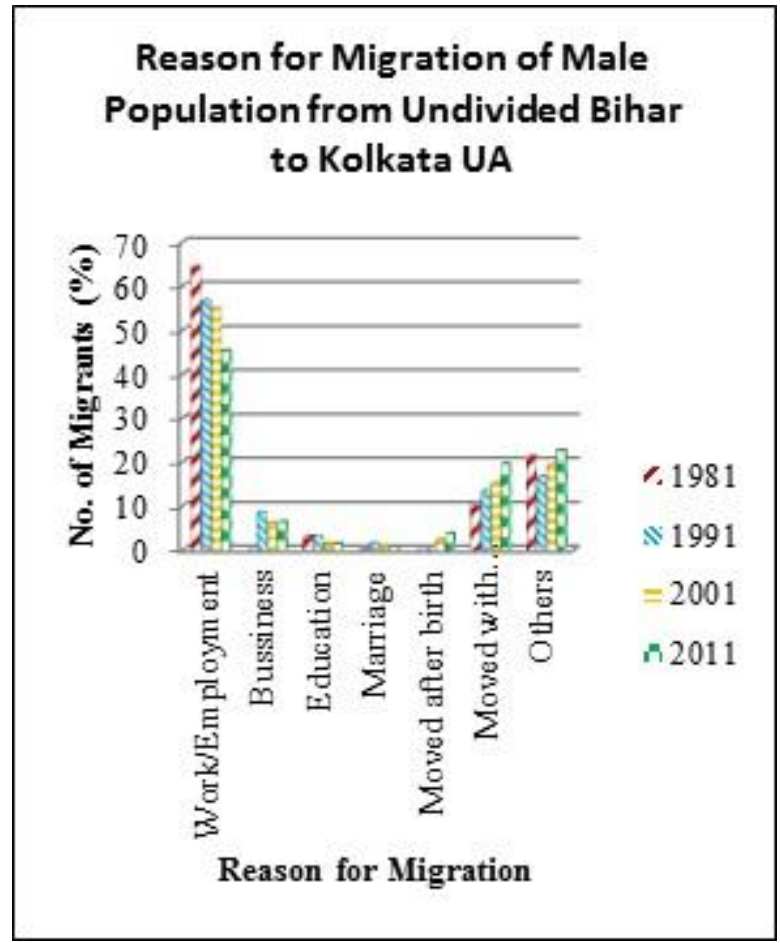

Figure 2
(2016) has stated that people not only migrate to Kolkata to search for jobs or to avail better job opportunities, but also to follow their ancestors. Field survey also depicts that a large number of migrants have migrated to this city because their father or other relatives were migrant labours in this city. So, from the very beginning it was predecided that they would migrate to Kolkata to work as a labour as these jobs offer sufficient money to run a family and they don't have to fulfil any educational or other criteria for entering in these jobs.

\section{Reason for Migration of Male Population from Uttar Pradesh to Kolkata UA}

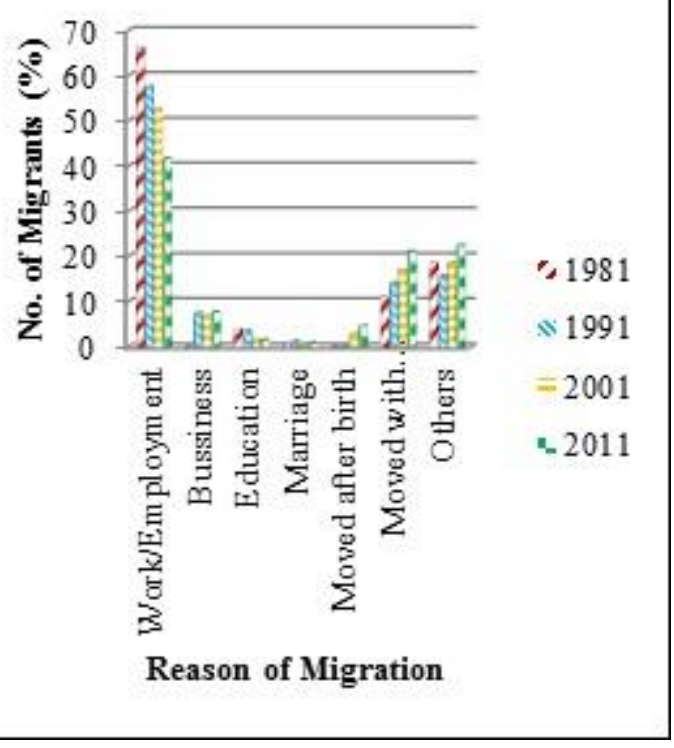

Figure 3

Source: Census of India, D-Series, West Bengal, 1981, 1991, 2001

During the field survey, most of the surveyed informal labours from Bihar have stated that there is a lack of employment opportunities in their village areas. One labour from Banka district, Bihar stated that in his village, 5 out of 10 households have at least one out-migrant in their family. The available jobs in rural areas of Bihar and Uttar Pradesh offer lower wages which push more informal labours to Kolkata where they can earn up to INR 500. The Mahatma Gandhi National Rural Employment Guarantee Act (MGNREGA) which was implemented by the Central Government in the year 2006 in 625 districts of India, is not working effectively. This act guaranteed to provide at least 100 days of wage employment in a financial year. At present, despite having MGNREGA cards, many people from villages are not getting work for more than 40 to 50 days in a year. The wage rate of MGNREGA in Bihar is quite low, around INR 120 only, which is another reason behind the decision to migrate to a metro city. Possession of agricultural land is also a significant factor of work or employment-induced migration.

\section{The Relation of Agricultural Land with Migration}

There is a negative correlation between the decision to migrate and the possession of agricultural land. Most of the surveyed informal 
labours do not possess any agricultural land. Other labours' land-holdings are too small to support a family for the whole year, which pushes them to decide out-migration in search of substitute jobs. Few labours said that though they have a handsome unit of agricultural land, they still migrate as there are other family members to look after the agricultural activities. Among the interviewed labours of different units, around 63 to 40 per cent labours do not have agricultural land (Table 4). Except for Burrabazar, possession of agricultural land varies

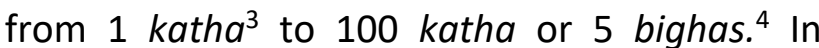
Burrabazar, one labour has stated that he has ten bighas of agricultural land which produces more than enough crops to run a family. Despite that, he migrated to another city because his brothers were there to look after the agricultural work.

\begin{tabular}{|c|c|c|c|c|c|c|c|c|}
\hline \multirow[t]{3}{*}{ Places } & \multirow[t]{3}{*}{ Borough } & \multirow{2}{*}{\multicolumn{2}{|c|}{ Total }} & \multicolumn{5}{|c|}{ Possession of Agricultural Land } \\
\hline & & & & \multicolumn{2}{|c|}{ Yes } & \multicolumn{2}{|c|}{ No } & \multirow[t]{2}{*}{ Quantity } \\
\hline & & No. & $\%$ & No. & $\%$ & No. & $\%$ & \\
\hline Posta & 4 & 30 & 100 & 13 & 43.33 & 17 & 56.67 & 12 Katha to 2 Bigha \\
\hline Burrabazar & 5 & 30 & 100 & 16 & 53.33 & 14 & 46.67 & 3 Katha to 10 Bigha \\
\hline Kailash Bose Street & 4 & 30 & 100 & 18 & 60.00 & 12 & 40.00 & 3 Katha to 5 Bigha \\
\hline Tangra & 7 & 30 & 100 & 11 & 36.67 & 19 & 63.33 & 1 Katha to 5 Bigha \\
\hline
\end{tabular}

The timings of visiting home also often depend upon the possession of the land. Most of the labours produce wheat and rice and sometimes lentil. The labours who grow crops once a year need to go to their village twice mandatorily, during sowing and during reaping the crops. In general, they sow paddy during the rainy season, mainly from June to July, and cut it during winter, mainly from November to December. Those who grow both paddy and wheat can sow wheat after cutting paddy. For cutting wheat, they have to go to their village again in March. The labours who grow crops twice a year have to visit their home three to four times necessarily. The time of visiting their homes also depends upon the religion of the labour. Muslim labours visit their home during Eid and other such festivals. On the other hand, all the Hindu labours attend Chhat Puja (Chhat Puja is celebrated in devotion to the Sun) in their villages. For other festivals like Diwali, the labours usually stay in the city as transactions in big market areas remain high during this season. Thus, they get an opportunity to earn more. Except for these festivals and seasons, they also visit their homes during emergencies or social occasions like marriages, first rice ceremony, etc.

\section{Conclusion}

This paper discusses and analyses in detail that the trend of in-migration from Bihar, Jharkhand and Uttar Pradesh to the informal labour market in Kolkata City has deep roots to the historical past. These three states provide around threefourths of the total inter-state migrants to West Bengal and Kolkata. More than half of the total migrants to West Bengal from Bihar are staying in Kolkata. It indicates that the trend of migration from Bihar is very significant in Kolkata as compared to any other district of West Bengal. The most dominant reason for migration from Bihar, Jharkhand and Uttar Pradesh to Kolkata is for work and employment. Lack of agricultural land is a common feature behind the inter-state migration to Kolkata's informal labour sector. However, occupation-induced male in-migration from both undivided Bihar and Uttar Pradesh is showing a declining trend to the city.

\footnotetext{
${ }^{4}$ Bigha is a unit of measuring land. 1 acre is equivalent to 2.5 bigha and 20 katha is equivalent to 1 bigha.

${ }^{3}$ Katha is a unit of measuring land. 1 acre is equivalent to 50 katha.
} 
Kolkata is a lucrative destination for informal labours due to its large informal sector and ease of entry. Bihar's long history of out-migration to Kolkata helps other aspirants to migrate to this city by providing ground information about the livelihood opportunities of the city. There is always a migrant family member or friend or relative or at least a neighbour to guide the new migrant. Because of this significant role of the social network in migration, every sector of the informal economy is dominated by a specific source region. In general, informal labours migrate from other states to the city without their family. They leave their family in the village to look after the agricultural activities and also to look after the elderly people and children at home. They send remittances to their family to support their survival in the village. Moreover, they cannot afford to run the family in Kolkata city, as the cost of living is very high. Due to 'single migration', the informal labours of Kolkata city never lose their connection with their village, which reduces the chances of their cultural adaptation in the city. As a result of this, they retain their cultural identity and develop their own cultural groups, remaining outsiders to the host city's citizens even after spending several decades in the city.

\section{References}

Banerjee, A. (2016). Migration in slums of Kolkata: Examining migrants' labour market outcomes. Working Paper. India: National Institute of Urban Affairs under SHRAMIC Portal.

Bhagat, R. B. (2011). Emerging pattern of urbanisation in India. Economic \& Political Weekly, 46(34), 10-12.

Bhatt, W. (2009). The gender dimension of migration in India: The politics of contemporary space in Orissa and Rajasthan. Development in Practice, 19(1), 87-93.

Bhattacharya, N., \& Chatterjee, A. K. (1973). Some characteristics of jute industry workers in Greater Calcutta. Economic and Political Weekly, 8(4/6), 297-308.
Census of India (1961). West Bengal and Sikkim, Migration Tables. India: Government of India Publications.

Census of India (1971). West Bengal, Migration Tables. India: Government of India Publications.

Census of India (1981). West Bengal, Migration Tables. India: Government of India Publications. Census of India (1991). West Bengal, Migration Tables. India: Government of India Publications Census of India (2001). West Bengal, Migration Tables. India: Government of India Publications.

Census of India (2011). West Bengal, Migration Tables. India: Government of India Publications.

Dasgupta, B. (1982). Migration and development: Major features of migratory movements in India. Paris, France: UNESCO.

Das, S., \& Das, M. (2014). Income, migration and social adjustment of the tribal people in Tripura: A case study of the 'Tripuri' tribe. Space and Culture, India, 2(1), 5-13.

De Haan, A. (1997). Unsettled settlers: Migrant workers and industrial capitalism in Calcutta. Modern Asian Studies, 31(4), 919-949.

De Haan, A. (1999). The badli system in industrial labour recruitment: Managers' and workers' strategies in Calcutta's jute industry. Contributions to Indian sociology, 33(1-2), 271301.

De Haan, A. (2000). Migrants, livelihoods, and rights: The relevance of migration in development policies. London: Social Development Department.

De Haan, A. (2002). Migration and livelihoods in historical perspective: A case study of Bihar, India. Journal of Development Studies, 38(5), 115-142.

Deshingkar, P., Kumar, S., Chobey, H. K., \& Kumar, D. (2006). The role of migration and remittances in promoting livelihoods in Bihar. London: Overseas Development Institute.

Kolkata Municipal Corporation (2009). Slum Survey Report. Kolkata, West Bengal: KMC. 
Narain, S., \& Bhattacharya, D. (2012). Why I left my village: $A$ study on migration from rural Bihar, India. India: Institute of Social Sciences.

Rana, K. (2018). Kolkata theke Kolikata. Desh, 85(20), 47-49.

Rao, G. D. (1973). Inter-state migration in India. The Indian Journal of Statistics, Series B (19602002), 35 (3), 367-376.

Ravenstein, E. G. (1885). The laws of migration. Journal of the Statistical Society of London, 48(2), 167-235.

Rele, J. R. (1969). Trends and significance of internal migration in India. Sankhyā: The Indian Journal of Statistics, Springer, Series $B$ (1960-2002), 31(3/4), 501-508.

Roy, B. K. (1991). On the questions of migration in India: Challenges and opportunities. GeoJournal, 23(3), 257-268.

Roy, A. K., Singh, P., \& Roy, U. N. (2015). Impact of rural-urban labour migration on education of children: A case study of left behind and accompanied migrant children in India. Space and Culture, 2(4), 17-34, https://doi.org/10.20896/saci.v2i4.74

Sen, S. (1999). At the margins: Women workers in the Bengal jute industry. Contributions to Indian Sociology, 33(1-2), 239-269.
Sharma, V. (2015). Are BIMARU states still Bimaru. Economic \& Political Weekly, 50(18), 58-63.

Singh, J. P. (1984). Distance patterns of rural to urban migration in India. Genus, 40(1-2), 119129.

Singh, J. P. (1985). Marital status and migration in Bihar, West Bengal and Kerala: A comparative analysis. Sociological Bulletin, 34(1-2), 69-87.

Skeldon R. (1986). On migration patterns in India during the 1970s. Population and Development Review, 12(4), 759-779.

Tobler, W. (1995). Migration: Ravenstein, Thornthwaite, and beyond. Urban Geography, 16(4), 321-343.

UNICEF (2014). Children of migrant poor in Kolkata: A study on human development perspectives. Kolkata, India: Institute of Social Sciences.

Zachariah, K. C. (1964). A historical study of internal migration in the Indian Sub-continent 1901-1931. Mumbai, India: Asia Publishing House.

\section{Acknowledgements}

This work is part of the IND-URBBS (India Urban-Rural Boundaries and Basic Services) research project supported by the French National Research Institute for Sustainable Development (IRD). 